\title{
FFPS news
}

\section{T. G. C. Vaughan-Jones, OBE, 1907-1986}

T. G. C. Vaughan-Jones, who died at Folkestone on 20 June 1986, never became as well known in the field of African wildlife conservation as the earlier pioneers, J. Stevenson-Hamilton and C. R. S. Pitman, yet his influence was as far reaching. Indeed, it was his practical implementation of Pitman's recommendations, together with innovations of his own, that paved the way for the modern African wildlife department we now perhaps tend to take for granted. He joined the Administration of what was then Northern Rhodesia in 1929 and, following Pitman's report on the 1930-1932 faunal survey (Pitman, 1934), submitted a memorandum on forming a game department in 1938, and drafted new legislation in 1939. The Department formally came into being in 1942, although not much could be done until 1945 when V.J., as he was known to his colleagues, was appointed full-time Director and could undertake its expansion. In those days one talked of 'game preservation' rather than fauna, flora and ecosystem conservation, and it was a far cry from the sophisticated organization we know today with its aerial census techniques, radio telemetry, visiting experts and so forth. These things, however, were the logical outcome of the foundations laid by VaughanJones. Perceiving that a department devoted solely to 'game' would be weak, he persuaded the Government to include tsetse control and fisheries as well, thus incorporating these biological disciplines into a single viable organization, though in the longer term they were again separated, as indeed he himself had envisaged. The Department was, I believe, the first in Africa to include a cadre of professional biologists on its establishment, and Vaughan-Jones's wisdom in following Pitman's broadly based approach ensured that it was not concerned only with game animals, but with all aspects of biological conservation. His beneficial influence continued after he left the Department when, in his capacity of Commissioner for Rural Development, he was able to arrange the visits of Dr (later Sir Frank) Fraser Darling in 1956 and 1957, the outcome of which was a stimulating publication on the integration of wildlife conservation with human needs and development in Africa (Fraser Darling, 134
1960). In 1948 Vaughan-Jones published a paper in which he outlined the aims and functions of the Department he had set up, and it is a measure of his far-sightedness that, notwithstanding the great political changes that have taken place since, much of what he then propounded remains the policy of the Zambian National Parks and Wildlife Service today.

W. F. H. Ansell

\section{References}

Fraser Darling, F. 1960. Wild Life in an African Territory Oxford University Press.

Pitman, C.R.S. 1934. A Report on a Faunal Survey of Northem Rhodesia with Especial Reference to Game, Elephant Control, and National Parks. Government Printer, Livingstone.

Vaughan-Jones, T.G.C. 1948. A short survey of the aims and functions of the Game and Tsetse Control Department of Northern Rhodesia. Rhodes-Livingstone Joumal. 6 . $37-48$.

\section{Oryx 100\% Fund grants}

At its meeting on 2 December 1986 the FFPS Council approved the following grants:

$\mathbf{£ 7 5 0}$ to Dr David MacDonald (Oxford, UK) to make a pilot study to determine the natural history, status and distribution of a fox species near the Dead Sea, Israel, which is as yet not positively identified and is previously unrecorded in the region.

$£ 364$ to Melanie Pilcher (Wye, UK) for micropropagation of Hyphorbe amaricaulis. This endemic Mauritian palm is known only from a solitary individual in Curepipe Botanical Gardens, and conventional propagation techniques have so far failed. Success with this project could lead to reintroduction of the species to Mauritius.

$\mathfrak{2 0 0}$ to Roger Beecroft (Ipswich, UK) to conduct a management survey of Kagoro Forest in Nigeria. Kagoro, an isolated area of relict high forest, contains many important animal and plant species, which are under pressure from hunting, farming and firewood collection.

$\mathbf{\$ 2 0 0}$ to Martin Kelsey (Oxford, UK) to conduct a workshop in Nairobi, Kenya,

Oryx Vol 21 No 2. April 1987 


\section{FFPS news}

where conservationists, the local Forestry Department and Kenyan governmental bodies can develop a conservation strategy for the ArabukoSokoke forest.

\section{Bat Project}

Thanks to the Nature Conservancy Council and the Vincent Wildlife Trust, both of which have provided substantial grant-aid, the FFPS Bat Project is continuing throughout 1987 . The success of 1986 National Bat Year means that large numbers of enquiries continue to come into the office, and there are plans for a wide range of new leaflets and other education aids for 1987. The London Borough Grants Scheme is providing a grant to continue monitoring bats in London.

The current FFPS bat team is Tony Hutson, Bat Conservation Officer, Simon Mickleburgh and Joan Tait, Assistant Bat Conservation Officers, and Joanna Price, who is carrying out research on serotine feeding ecology. The FFPS is most anxious to extend its commitment to international bat conservation, and Tony Hutson has recently been appointed Secretary to the IUCN Chiroptera Specialist Group. Current problems include nuclear waste dumping in bat caves in Poland, and pesticide spraying in Israel; donations to support the overseas work are particularly urgently needed.

\section{Herpetofauna Project}

\section{Protecting Britain's commoner reptiles} and amphibians

In November 1986, the FFPS published a report, Protecting Wild Reptiles and Amphibians in Britain. It drew attention to numerous documented cases of cruelty to and needless killing of Britain's amphibians and reptiles, pointing out that, although this was a welfare issue, it also had implications for conservation. It examined the legislation that might be invoked in such cases, found it to be inadequate, and concluded by recommending ways in which this could be remedied. One of these, a call for stricter legislation, came just as the Department of the Environment also released a public consultation document on changes to the Schedules of the FFPS news
Wildlife and Countryside Act (1981/85). It contains a recommendation that the grass snake, common lizard, adder and slow worm should be protected from killing and injury, but not from uncontrolled taking or commercial sale. The review recommended no protection for Britain's four commoner amphibians. As a result, the FFPS is now assisting with the drafting of an Amendment Bill to the Wildlife and Countryside Act (1981/85) and the Protection of Animals Act (1911), Scotland (1912), which would make the malicious killing or injury of these animals illegal.

The production of the report was assisted by funding from the RSPCA and the Nature Conservancy Council and is available for $£ 5.00$, including postage, from FFPS, c/o Zoological Society of London, Regent's Park, London NW1 4RY, UK.

\section{To plant a tropical forest}

Dr Dan Jansen of Philadelphia University, USA, who has been carrying out field work in Costa Rica for over a decade, has developed an exciting new project to 'plant a tropical forest'. His idea is to recreate the Guancaste National Park using the fragmented remains of the tropical forest. A BBC team filming in Costa Rica contacted the FFPS and the Society organized a small seminar, together with the Entomology Department of the British Museum (Natural History), at which Dr Jansen presented his ideas.

An ambitious target of $\$ 11$ million is needed, but by the end of 1986 nearly $\$ 2$ million was pledged, and an article by Jeremy Cherfas in the New Scientist Christmas issue brought in over $£ 1500$ for the fund that the FFPS is holding for the project.

An information pack is available from the FFPS (please send a large, stamped addressed envelope).

\section{Accommodation needed for reputable society}

When, in October 1985, the FFPS moved from its long-time home in the Zoological Gardens in Regent's Park to temporary accommodation in Camden High Street, it was with the hope that the Zoological Society could rehouse us one day. It now seems that that day may be too distant; our 


\section{FFPS news}

lease on the offices in Camden Town will expire long before the Zoo can provide any new accommodation.

The Society, therefore, is urgently seeking a new, permanent home, and if you know of any properties in or around London that might be suitable-especially if they are cheap (or even free) - we would be delighted to hear from you. Please contact the FFPS office if you have any information that may help us find a new home. May we also remind you that our Premises Appeal Fund is still open for contributions; it currently stands at $£ 5954$, but we hope it will grow. We would also welcome legacies or donations of property towards the Fund.

\section{Wildlife Photographer of the Year- exhibition on tour}

The exhibition of winning photographs in the 1986 Wildlife Photographer of the Year competition is touring Britain in 1987; the list below gives dates and locations.

\begin{tabular}{|c|c|}
\hline $\begin{array}{l}22 \text { March- } \\
2 \text { May }\end{array}$ & $\begin{array}{l}\text { University of Oxford, University } \\
\text { Museum, Parks Road, Oxford } \\
\text { OX1 3PR. }\end{array}$ \\
\hline 3 May- & King's Lynn Museum, Old \\
\hline 13 June & $\begin{array}{l}\text { Market Street, King's Lynn } \\
\text { (on the Bus Station). }\end{array}$ \\
\hline $\begin{array}{l}14 \text { June- } \\
25 \text { July }\end{array}$ & $\begin{array}{l}\text { The Manor House Art Gallery } \\
\text { and Museum, Castle Yard, } \\
\text { Ilkley, West Yorks LS29 9DT. }\end{array}$ \\
\hline 26 July- & Aberystwyth Arts Centre, \\
\hline 5 September & $\begin{array}{l}\text { University College of Wales, } \\
\text { Aberystwyth SY23 3DE. }\end{array}$ \\
\hline 6 September- & London Ecology Centre, \\
\hline & $\begin{array}{l}45 \text { Shelton Street, } \\
\text { London WC2H } 9 \mathrm{HJ} .\end{array}$ \\
\hline $\begin{array}{l}18 \text { October- } \\
28 \text { November }\end{array}$ & $\begin{array}{l}\text { Royal Museum of } \\
\text { Scotland, Chamber's Street, } \\
\text { Edinburgh EH1 1JE. }\end{array}$ \\
\hline & Ulster Museum, Botanic \\
\hline & Gardens, Belfast BT9 5AB. \\
\hline
\end{tabular}

\section{Record growth for FFPS}

Towards the end of 1986 the FFPS gained its 4000th member-Dr Tom Butynski, a scientist working to save mountain gorillas in Ugandaand recorded its highest ever membership. This 136 satisfying event was the outcome of a membership campaign in 1986 during which the Society increased its membership by 20 per cent. Since membership provides the bulk of our income, we are able to expand our conservation activities with every new member. Please help us to continue our growth and our work by getting a friend to fill in the membership form at the front of this issue.

\section{Director for FFPS (Inc.)}

On 1 January 1987 Duane Pierson took up his appointment as the first Executive Director of FFPS (Inc.).

Honorary Director, John Walsh of the World Society for the Protection of Animals in Boston, is providing an office, and Dr Gerard Bertrand and other FFPS members are helping to establish it.

Any FFPS members within the New England area who think they can offer any help are encouraged to contact Duane Pierson on 617-524-9656.

\section{Members' meetings}

For London and local group meetings please see the insert in this issue of Oryx.

The contact people for local group meetings are given below. Please send a stamped selfaddressed envelope with enquiries.

\section{Bristol and the West of England Group}

Ian Redmond, 60 Seymore Avenue, Bishopston, Bristol BS7 9HN.

\section{Cambridge Group}

Sandy Harcourt, University of Cambridge, Department of Applied Biology, Pembroke Street, Cambridge CB2 3DX.

Friday 15 May: An evening with orchids.

\section{Oxford Group}

David Macdonald, Department of Zoology, University of Oxford, South Parks Road, Oxford OX1 3PS.

\section{North-West Group}

Nick Ellerton, Chester Zoo, Caughall Road, Upton, Chester $\mathrm{CH} 2 \mathrm{LL}$.

Oryx Vol 21 No 2, April 1987 